\title{
Peningkatan Pemahaman dan Partsipasi Pencegahan Korupsi bagi Mahasiswa Manggarai di Kota Makassar
}

\section{Wencislaus S. Nansi*1, Antonius Sudirman²}

\author{
${ }^{1,2}$ Fakultas Hukum, Universitas Atma Jaya Makassar, Indonesia \\ *e-mail: wencislaus82@gmail.com ${ }^{1}{ }_{\text {dantonius.Sudirman@gmail.com }}^{2}$
}

\begin{abstract}
Abstrak
Di Indonesia korupsi dikategorikan sebagai extra ordinary crime atau kejahatan luar biasa, sebab korupsi bukan saja dilakukan secara individu. Namun, dilakukan secara terorganisir, sistematis dan terstruktur oleh kelompok atau istitusi yang menyebabkan kerugian besar bagi rakyat dan perekonomian bangsa. Untuk itu penting dilakukan berbagai upaya pencegahan dan penanggulangan budaya korupsi dengan melibatkan berbagai elemen bangsa termasuk mahasiswa agar berpartisipasi secara aktif untuk mengawal berbagai isu-isu korupsi dan mengontrol berbagai kerja lembaga-lembaga negara dan aparat penegak hukum agar terhindar dari praktek korupsi. Dari sekian bannyak komunitas/ elemen masyarakat yang ada, kegiatan pengabdian masyarakat kali ini kami fokuskan pada komunitas mahasiwa Asal Manggarai-Flores-Nusa Tenggara Timur yang sedang menempu pendidikan di Kota Makassar. Kegiatan yang telah kami lakukan berupa peyuluhan hukum anti korupsi dan membangun gerakan bersama melawan korupsi. Kegiatan yang dilakukan ini menggunakan metode ceramah, analisis kasus, pemutaran video gerakan anti korupsi serta tindakan nyata berupa membentuk Forum anti Korupsi. Hasil kegiatan yang telah dilakukan adalah pemahaman dasar tentang kejahatan Korupsi serta meningkatnya kesadaran tentang pentingnya partisipasi melalui gerakan bersama melawan korupsi. Selain itu hasil yang dicapai adalah menanamkan nilai-nilai dan sikap anti korupsi bagi mahasiswa Manggarai yang ada Makassar.
\end{abstract}

Kata kunci: Korupsi, Partisipasi, Pencegahan, Peningkatan, Pemahaman

In Indonesia, corruption is categorized as an extraordinary crime, because corruption is not only carried out individually, but is carried out in an organized, systematic and structured manner by groups or institutions which causes great losses for the people and the nation's economy. For this reason, it is important to carry out various efforts to prevent and overcome the culture of corruption by involving various elements of the nation, including students, to actively participate in guarding various corruption issues and controlling the work of state institutions and law enforcement officials in order to avoid corrupt practices. Of the many communities/ community elements that exist, this time we focus on the community of students from Manggarai-Flores-East Nusa Tenggara who are studying in Makassar City. The activities we have carried out are in the form of counseling on anti-corruption laws and building a joint movement against corruption. This activity uses the lecture method, case analysis, video screening of the anti-corruption movement and concrete actions in the form of forming an anti-corruption forum. The results of the activities that have been carried out are a basic understanding of the crime of corruption and increased awareness of the importance of participation through a joint movement against corruption. In addition, the results achieved are to instill anti-corruption values and attitudes for Manggarai students in Makassar.

Keywords: Corruption, Improvement, Participation, Prevention, Understanding

\section{PENDAHULUAN}

Di Indonesia dewasa ini, korupsi menjadi salah satu isu penting yang terus-menerus dikampanyekan untuk dilawan. Hal ini disebabkan karena korupsi seakan sudah menjadi kebiasaan dan budaya anak bangsa yang menjangkiti semua orang pada setiap level kekuasaan dan pemerintahan, baik eksekutif, legislative, maupun yudikatif dari tingkat pusat sampai ke daerah.

Apabila dilihat dari akar katanya, Tindak Pidana Korupsi dalam Bahasa latin disebut corruption atau corruptus. Menurut Webster Student Dictionary, korupsi digambarkan dengan menggunakan istilah "corruptus". (http:/www.wordcentral.com/cgibin/student?book=Student\&va=corrupt diakses 12 Agustus 2018.) Andi Hamzah (1995: 135) 
menyatakan bahwa korupsi berasal dari Bahasa Latin yaitu "corruption" atau "corruptus" yang kemudian muncul dalam banyak Bahasa Eropa seperti Inggris dan Parancis yaitu "corruption", dalam Belanda "korruptie" yang selanjutnya muncul pula dalam perbendaharaan Bahasa Indonesia: korupsi, yang berarti suka disuap.

Pengertian Tindak Pidana Korupsi menurut Ensiklopedia Indonesia: Korupsi (berasal dari Bahasa Latin, Corruption sama dengan penyuapan;dari corrumpere sama dengan merusak). Gejala di mana para pejabat badan-badan Negara menyalahgunakan jabatan mereka, sehingga memungkinkan terjadinya penyuapan, pemalsuan serta ketidakberesan lainnya. Sementara Kamus Besar Bahasa Indonesia (Wasito: 2001:597) memberikan pengertian tentang korupsi sebagai penyelewengan atau penyalahgunaan uang negara (perusahaan) untuk keuntungan pribadi atau orang lain.

Sejalan dengan pengertian tersebut, banyak pakar juga memberikan defenisi tentang Tindak Pidana Korupsi. Menurut Mohtar Mas'oed(1997:25) Tindak Pidana Korupsi sebagai perilaku menyimpang dari kewajiban formal suatu jabatan publik karena kehendak untuk memperoleh keuntungan ekonomis atau status bagi diri sendiri, keluarga dekat atau kerabat. Selanjutnya Baharudin Lopa (1987:6) mengungkapkan bahwa Tindak Pidana Korupsi adalah tindak pidana yang berhubungan dengan perbuatan penyuapan dan manipulasi serta perbuatan-perbuatan lain yang merugikan keuangan negara atau perekonomian negara, merugikan kesejahteraan dan kepentingan rakyat.

Dari beberapa pengertian tersebut, dalam Undang-Undang 20 Tahun 2001 sebagai perubahan dari undang-undang No.31 Tahun 1999 tentang Tindak Pidana Korupsi, Tindak Pidana Korupsi dapat diklasifikasi dalam beberapa kelompok, yakni: (Kristian, 2015:48) a.) Kelompok Tindak Pidana Yang dapat Merugikan Keuangan atau perekonomian negara, b)Kelompok Tindak Pidana Penyuapan, baik aktif (yang menyuap) maupun Pasif (yang disuap) serta gratifikasi, c.)Kelompok Tindak Pidana Penggelapan, d.)Kelompok Tindak Pidana Pemerasan dalam jabatan (knevelarij, extortion), e.) Kelompok Tindak Pidana Pemalsuan, f.)Kelompok Tindak Pidana yang berkaitan dengan pemborongan, laverensir, dan rekanan.

Berdasarkan hal tersebut, maka Tindak Pidana Korupsi merupakan bentuk kejahatan dengan dimensi yang sangat luas. Dalam buku tulisan Kristian dan Yopi Gunawan (2015:48-54) mengulas beberapa karakteristik Tindak Pidana korupsi, yakni:

a. Tindak Pidana Korupsi sebagai Kejahatan Kerah Putih (White collar Crime) White Collar Crime (WCC): yaitu kejahatan yang dilakukan oleh orang yang berkelebihan kekakayaan dan dipandang terhormat, karena mempunyai kedudukan penting baik dalam pemerintahan maupun dalam dunia perekonomian. Selanjutnya Sutherland menyatakan bahwa White Collar Crime merupakan suatu tindak pidana yang dilakukan oleh mereka dari kalangan atas yang berkedudukan sosial tinggi dan terhormat dan dilakukan dalam pekerjaannya (crime committed by person of respectability and high social status in the course of their occupation, berupa penipuan canggih oleh para eksekutif senior (the sophisticated frauds of senior executives) (Shofie:2002:44). Selanjutanya, karakteristik kejahatan kerah Putih atau white collar crime, dapat dijabarkan oelh mahrus Ali (sebagai berikut: 1) Low Visibility artinya kejahatan kerah putih merupakan kejahatan yang sulit dilihat karena biasanya ditutup oleh kegiatan pekerjaan yang normal dan rutin yang melibatkan keahlian. 2)Complexity artinya bahwa kejahatan kerah putih bukanlah kejahatan sederhana tetapi sangat kompkleks karena berkaitan dengan kebohongan, penbipuan dll, yang berjalan bertahun-tahun.3) Defussion Of Responsibility artinya dalam kejahatan kerah putih terjadi penyebaran tanggungjawab yang sangat luas. 4)Deffusion of Viktimization artinya adalah dalam kejahatan kerah putih terjadi penyebaran korban yang sangat luas. 5)Detection And Proccution artinya adalah adanya ketidakseimnbangan antara kemampuan aparat penegak hukum dan kecanggihan serta kemampuan dari pelaku.

b. Tindak Pidana Korupsi sebagai Kejahatan terorganisir (organized crime) IS. Susanto (1995:27) menyatakan kejahatan terorganisasi adalah suatu kejahatan yang terjadi dalam konteks hubungan-hubungan yang kompleks. Tindak pidana yang terorganisasi pada umumnya terdiri dari tiga unsur utama: 1) Adanya organisasi kejahatan (criminal group) yang sangat solid 2) Adanya kelompok yang melindungi kepentingan kelompok ini 
(protector) 3).Kelompok masyarakat yang menikmati hasil kejahatan atau tindak pidana yang dilakukan secara sistematis tersebut.

c. Tindak Pidana Korupsi sebagai kejahatan lintas batas Negara yang terorganisasi (transnational organaized crime) Tindak Pidana Korupsi dapat dikategorikan sebagai kejahatan transnasional yang bersifat terorganisir. Hal tersebut karena Tindak Pidana Korupsi selalu melibatkan orang-orang yang membentuk sebuah jaringan atau sistem yang terorganisir melampau batas negara.

d. Tindak Pidana Korupsi sebagai tindak pidana yang berdampak luar biasa (extra Ordinary crime). Tindak Pidana Korupsi dapat pula dianggap sebagai kejahatan berdampak luar biasa. Dalam pertimbangan The United Nations Convention Against Corruption (UNCAC) dikemukan dengan tegas bahwa negara-negara didunia prihatin akan ancaman dan akibat yang ditimbulkan oleh Tindak Pidana Korupsi terhadap stabilitas keamanan masyarakat, yang merusak lembaga-lembaga dan nilai-nilai demokrasi, moral dan etika dan keadilan serta mengacaukan pembangunan yang berkelanjutan dan pengakan hukum. Hakl tersebut selaras dengan penjelasan UU. No. 20 Tahun 2001 tentang Pemberantasan Tindak Pidana Korupsiyang menyatakan: "...... mengingat korupsi di Indonesia terjadi secara sistematik dan meluas sehingga tidak hanya merugikan keuangan negara, tetapi juga telah melanggar hakhak social dan ekonomi masyarakat secara luas, maka pemberantasan korupsi perlu dilakukan dengan cara luar biasa...."

e. Tindak Pidana Korupsi sebagai kejahatan dengan dimensi-dimensi yang baru Tindak Pindana Korupsi merupakan tindak pidana dengan modus-modus yang baru, seperti ratifikasi, money loundring dll. Hal tersebut terjadi seiring dengan perkembangan ilmu pengetahuan dan tehnologi.

Meskipun kampanye berlangsung di berbagai tingkat mulai dari pusat hingga daerah, namun sepertinya tidak ada perbaikan yang signifikan. Korupsi seolah tetap bertahan dan bahkan terus membiakkan diri. Kejahatan Korupsi ini dari tahun ketahun tidak menunjukan perubahan yang baik bahkan lebih buruk, hal tersebut diafirmasi kembali berdasarkan hasil Survei Dari Transparancy International Indonesia (Sumber:https://www.antaranews.com/berita/1972407/indeks-persepsi-korupsi) bahwa Coruption Perception Index atau Indeks Persepsi Korupsi Indonesia pada tahun 2020 melorot tiga point menjadi 37 dari 40 pada tahun sebelumnya 2019 dan Indonesia berada pada posisi 102 dari 180 negara terkorup yang disurvei. Salah satu aspek yang menyumbang tingginya nilai korupsi di Indonesia adalah korupsi politik, korupsi di lembaga eksekutif, legislative dan Yudikatif. Data KPK mengafirmasi hal tersebut dimana tindak pidana korupsi tersebar hampir seluruh institusi Negara. Dari Data terungkap bahwa tahun 2018-2020 korupsi tersebar disemua institusi seperti DPR/DPRD: 130 Kasus, Kepala Lembaga/Kementrian: 3 Kasus, Gubernur: 3 Kasus, Walikota/Bupati: 52 Kasus, Hakim: 5 Kasus, Jaksa: 3 Kasus, Pengacara: 5 Kasus (https://www.kpk.go.id/id/statistik/penindakan/tpk-berdasarkan-profesi-jabatan).

Banyak studi yang dilakukan dalam rangka melacak akar penyebab korupsi. Theodore $\mathrm{M}$ Smith (1993) mencatat setidaknya ada enam penyebab muncul dan berkembangnya korupsi di Indonesia. Pertama, faktor politik, yakni terkait kemauan dan iktikad baik rezim dan elite politik dalam menyelesaikan kasus korupsi. Kedua, faktor yuridis, yakni terkait persoalan perundangundangan dan sanksi hukum terhadap koruptor yang lemah. Ketiga, faktor budaya, yakni terkait dengan perkembangan pandangan feodalistik dan sikap ingin dilayani serta hidup mewah. Keempat adalah faktor administrasi pemerintahan. Ini berkaitan dengan kelemahan pengawasan yang akhirnya berpotensi membuka peluang korupsi. Kelima, faktor insentif ekonomi yang tidak berimbang sehingga cukup memancing aparat birokrasi mencari tambahan dengan menyalahgunakan wewenang. Keenam, faktor historis yang terkait dua warisan utama kolonialisme, yakni mental korup dan struktur pemerintahan yang berorientasi menjadi pelayan atasan ketimbang pelayan masyarakat.

Dari sekian banyak factor tersebut, kurang lebih factor utama adalah rendahnya integritas para pelakunya dan masih kentalnya budaya permisif terhadap tindakan korupsi. Masyarakat banyak berada pada lingkaran kultur yang justru mendukung struktur social berprilaku koruptif. Korupsi awalnya merupakan prilaku individu namun perlahan-lahan 
berubah bentuk menjadi sebuah kebudayaan baru karena hampir pasti menjadi kebiasaan yang sulit untuk dihilangkan.

Dalam konteks kita di Indonesia, korupsi merupakan salah satu kejahatan yang dikategorikan sebagai extra ordinary crime atau kejahatan luar biasa. Dikatakan kejahatan luar biasa karena korupsi bukan saja dilakukan secara individu, namun dilakukan secara teroragisir, sistematis dan terstruktur oleh kelompok atau istitusi yang menyebabkan kerugian besar bagi rakyat dan perekonomian bangsa.

Untuk itu penting dilakukan berbagai upaya pencegahan dan penanggulangan budaya korupsi. Salah satu upaya yang dilakukan adalah dengan pengembangan sistem nilai dan sikap anti korupsi. Hal tersebut dapat dilakukan melalui berbagai kampanye serta memberikan ruang bagi masyarakat untuk turut berpartisipasi dalam upaya pemberantasan korupsi. Ada enam strategi nasional dalam upaya pemberantasan korupsi yakni(1) melaksanakan upaya pencegahan, (2)melaksanakan langkah-langkah strategis di bidang penegakan hukum, (3)melaksanakan upaya-upaya harmonisasi penyusunan peraturan perundang-undangan di bidang pemberantasan korupsi dan sektor terkait lainnya, (4)Melaksanakan kerjasama internasional dan penyelamatan aset hasil tindak pidana korupsi, (5)meningkatkan upaya pendidikan dan budaya anti korupsi, (6)meningkatkan koordinasi dalam rangka mekanisme pelaporan pelaksanaan upaya pemberantasan korupsi.

Dari beberapa strategi tersebut, salah satu kanal utamanya adalah melalui peningkatan partisipasi masyarakat, seperti NGO, organisasi masyarakat, serta oraganisasi kemahasiswaan melalui strategi pendidikan dan internalisasi nilai-nilai dan budaya anti korupsi di lingkungan komunitas tersebut. Salah satu yang menjadi komunitas target pemberdayaan hukum dalam rangka peningkatan partisipasi pencegahan kejahatan korupsi adalah mahasiwa Asal Manggarai-Flores-Nusa Tenggara Timur yang sedang menempu pendididkan di Kota Makassar.

Adapun beberapa permasalahan mitra yang menjadi alasan pelaksanaan kegiatan pengabdian masyarakat ini adalah sebagai berikut.

a. Masih kurangnya pemahaman mahasiwa Manggarai-NTT di Kota Makassar tentang korupsi seperti struktur dan bentuk korupsi, Faktor dan upaya pencegahan korupsi.

b. Masih rendahnya tingkat partisipasi Mahasiswa Manggarai di Makassar untuk terlibat dalam pengawasan kerja-kerja lembaga atau institusi penegak hukum serta terlibat mengawal berbagai dugaan kejahatan korupsi secara nasional maupun regional.

Berdasarkan permasalahan tersebut maka tujuan dari kegiatan yang telah dilakukan ini adalah : a) Memberikan pemahaman yang komprehensif tentang korupsi seperti struktur dan bentuk korupsi, Faktor dan upaya pencegahan korupsi, b) Membangun gerakan bersama bagi mahasiswa Manggarai di Kota Makassar untuk bersama-sama melawan korupsi, c) Mendorong Partisipasi aktif Mahasiswa Mannggarai di Makassar untuk terlibat dalam pengawasan kerjakerja lembaga atau institusi penegak hukum serta mengawal berbagai dugaan kejahatan korupsi secara nasioanal, d) Menyiapkan kader Bangsa Masa depan dengan semangat zero toleransi terhadap korupsi.

\section{METODE}

Pelaksanaan kegiatan pengabdian kepada masyarakat ini menggunakan metode ceramah, diskusi, dan analisis kasus.

a. Dalam Metode ceramah peserta diberikan penyuluhan hukum tentang korupsi, seperti defenisi, factor penyebab, serta upaya-upaya pencegahan yang harus dilakukan. Pada metode ini peserta diberikan beberapa materi dan referensi dasar tentang korupsi seperti teori dan peraturan perundang-undangan tentang korupsi

b. Dalam metode diskusi, peserta diberikan kesempatan untuk bertanya dan memeberikan gagasan berkaitan dengan upaya-upaya pemberantasan korupsi di Indonesia.

c. Dalam metode Analisis Kasus, peserta diajak untuk menganalisis kasus-kasus korupsi yang yang terjadi di Indonesia (dipilih beberapa contoh kasus aktul dan dianggap popular dan kontroversial). 


\section{HASIL DAN PEMBAHASAN}

\subsection{Pentingnya Partisipasi Mahasiswa Manggarai NTT di Kota Makassar dalam Upaya Pencegahan Korupsi}

Dalam upaya pemberantasan korupsi, tentunya tidak hanya menjadi tugas dan tanggung jawab aparat penengak hukum. Namun juga diperlukan peran serta masyarakat. Peran serta masyarakat dalam hal ini adalah dalam bentuk pegawasan terhadap praktik penyelenggaraan pemerintahan. Peran serta masyarakat diartikan sebagai peran aktif organisasi masyarakat, perorangan, atau lembaga swadaya masyarakat dalam pencegahan dan pemberantasan tindak pidana korupsi. Wujud peran serta masyarakat dapat dilaksanakan dengan cara: a) Peran serta melalui media massa: Koran, majalah, radio, dan televise maupun media-media social yang tersedia saat ini.

Adanya dugaan kasus korupsi yang terjadi di suatu lembaga pemerintah atau dugaan korupsi oleh seorang pejabat negara dapat diberitakan melalui media massa maupun mediamedia sosial. Melalui media, masyarakat juga dapat menyampaikan adanya dugaan korupsi, kejadian korupsi, atau hal lain yang berkaitan. b) Peran serta melalui kegiatan-kegiatan langsung dan terbuka oleh sekelompok orang berkaitan dengan upaya penanggulangan korupsi. Contohnya, unjuk rasa mendatangi lembaga pemerintahan, DPR/DPRD, gedung KPK, dll Lembaga swadaya masyarakat (LSM) sekarang ini banyak sekali yang berkecimpung di bidang penanggulangan korupsi. Secara aktif dan rajin mereka melakukan kegiatan-kegiatan yang berintikan upaya menanggulangi korupsi, seperti melaporkan adanya tindak pidana korupsi oleh seorang pejabat, memberikan masukan dan kritik terhadap penggunaan anggaran suatu departemen, laporan dugaan korupsi suatu departemen, dan lain-lain.

Masyarakat tentunya tidak perlu takut dan ragu dalam melakukan pengawasan dan partispasi dalam upaya pencegahan korupsi, sebab Negara sudah mengatur dan memberikan perlindungan hukum. Beberapa norma hukum yang menjadi dasar peran partisipasi masyarakat diantaranya:

a. Kitab Undang-undang Hukum Pidana (KUHP). Dalam pasal 108 ayat 1 dan ayat 2 menegaskan bahwa:

(1) Setiap orang yang mengalami, melihat, menyaksikan dan atau menjadi korban peristiwa yang merupakan tindak pidana berhak untuk mengajukan laporan atau pengaduan kepada penyidik dan atau penyidik, baik lisan maupun tertulis;

(2) Setiap pegawai negeri dalam rangka melaksanakan tugasnya yang mengetahui tentang terjadinya peristiwa yang merupakan tindak pidana wajib segera melaporkan hal itu kepada penyelidik atau penyidik.

b. Undang-undang No. 31 Tahun 1999 jo Undang-Undang No. 20 Tahun 2001 tentang Pemberantasan Tindak Pidana Korupsi. Pada pasal 41 ayat 2 disebutkan bahwa peran serta masyarakat dalam pemberantasan Tindak Pidana Korupsi dapat diwujudkan dalam bentuk:

a) Hak untuk mencari, memperoleh dan memberikan informasi adanya dugaan telah terjadi Tindak Pidana Korupsi; b) Hak untuk memperoleh pelayanan dalam mencari, memperoleh dan memberikan informasi adanya dugaan telah terjadi Tindak Pidana Korupsi kepada penegak hukum yang menangani perkara Tindak Pidana Korupsi; c) Hak menyampaikan saran dan pendapat secara bertanggung jawab kepada penegak hukum yang menangani perkara Tindak Pidana Korupsi; d) Hak untuk memperoleh jawaban atas pertanyaan tentang laporannya yang diberikan kepada penegak hukum dalam waktu paling lama 30 (tiga puluh) hari; e) Hak untuk memperoleh perlindungan hukum dalam hal: Melaksanakan haknya sebagaimana dimaksud dalam huruf a, b, dan c; dan diminta hadir dalam proses penyelidikan, penyidikan dan di siding pengadilan sebagai saksi pelapor, saksi atau saksi ahli, sesuai dengan ketentuan peraturan perundang-undangan yang berlaku.

c. Undang Undang Nomor 30 tahun 2002 tentang Komisi Pemberantasan Korupsi

Pada Pasal 1 ayat 3 UU KPK mengatur soal peran serta masyarakat dimana disebutkan bahwa Pemberantasan korupsi adalah serangkaian tindakan untuk mencegah dan memberantas tindak pidana korupsi melalui upaya koordinasi, supervisi, monitor, 
penyelidikan, penyidikan, penuntutan dan pemeriksaan di sidang pengadilan dengan peran serta masyarakat berdasarkan peraturan undang-undang yang berlaku.

d. Peraturan Pemerintah Republik Indonesia Nomor: 71 Tahun 2000 tentang Tata Cara Pelaksanaan Peran Serta Masyarakat dan Pemberian Penghargaan Dalam Pencegahan dan Pemberantasan Tindak Pidana Korupsi

Dalam Peraturan Pemerintah ini diatur beberapa hal yang berkaitan peran serta masyarakat, diantarnya:

a. Hak dan tanggung jawab masyarakat dalam mencari, memperoleh, memberi informasi, saran dan pendapat

b. Hak dan tanggung jawab masyarakat dalam memperoleh pelayanan dan jawaban dari penegak hukum

c. Hak dan tanggung jawab masyarakat dalam memperoleh perlindungan hukum.

Berdasarkan beberapa ketentuan peraturan perundang-undangan tersebut, maka mendorong pengabdi untuk melakukan kegiatan pengabdian masyarakat dengan melibatkan sasaran mahasiswa Manggarai-NTT yang sedang menempuh pendidikan di Kota Masyarakat. Selain itu, ada beberapa dasar pertimbangan memilih Mahsiswa Manggarai NTT di Kota Makasar sebagai sasaran kegiatan yakni:

a. Mahasiswa secara umum, termasuk mahasiswa Manggarai yang sedang menempuh pendidikan di Kota Makassar memiliki peran dan tanggung jawab terhadap Bangsa dan Negara, termasuk mengawal serta mengotrol berbagai prilaku yang merusak tatanan kehidupan bangsa seperti korupsi baik yang terjadi secara nasional maupun dalam lingkup pemerintah daerah, khususnya Manggarai-NTT.

b. Mahasiswa Manggarai yang ada di Kota Makassar mengambil kuliah dalam beberapa kampus dengan jurusan beragam, tidak hanya mahasiswa hukum tetapi juga belajar ilmu bukan hukum. Hal Ini tentunya mempengaruhi pemahaman mereka tentang konsep korupsi yang merupakan domain ilmu hukum. Oleh karena itu pentingnya pemahaman yang komprehensif khususnya yang bukan mahasiswa hukum tentang gambaran umum tentang korupsi, penyebab serta upaya pencegahannya.

c. Banyak isu-isu nasional maupun regional berkaitan dengan korupsi yang seyogyanya penting direspon oleh mahsiswa Manggarai, namun karena keterbatasan mereka tentang pemahaman korupsi maupun prosedur pelaporan akhirnya mereka seolah-olah menjadi pasif dan terkesan permisif terhadap korupsi. Oleh karena itu kegiatan ini menjadi sangat penting bagi mereka.

d. Mahasiswa Manggarai adalah calon pemimpin masa depan yang bekerja baik daalam sektor swasta maupun pemerintahan. Oleh jarena itu seyogyanya tidak hanya memiliki kemampuan intelektual tetapi juga harus memiliki integritas sehingga tidak terjebak pada praktek-praktek korupsi.

\subsection{Bentuk-Bentuk Kegiatan Pengabdian Kepada Mahasiswa Manggarai di Kota Makassar}

Kegiatan peningkatan Pemahaman dan Partisipasi Pencegahan Korupsi Terhadap Mahasiswa Manggarai-NTT di Kota Makassar, dilakukan dalam tiga bentuk:

\subsubsection{Penyuluhan Hukum}

Kegiatan ini bertujuan untuk:

a. Memberikan gambaran dan pengetahuan yang komprehensif bagi mahasiswa Manggarai tentang korupsi seperti struktur dan bentuk korupsi, Faktor serta upaya-upaya pencegahan korupsi,

b. Memberikan gambaran tentang beberapa kasus korupsi yang terjadi di Indonesia dan bagaimana upaya upaya penyelesaiannya,

c. Mengurai berbagai bentuk peraturan perundang-undangan yang berkaitan dengan kejahatan korupsi di Indonesia 


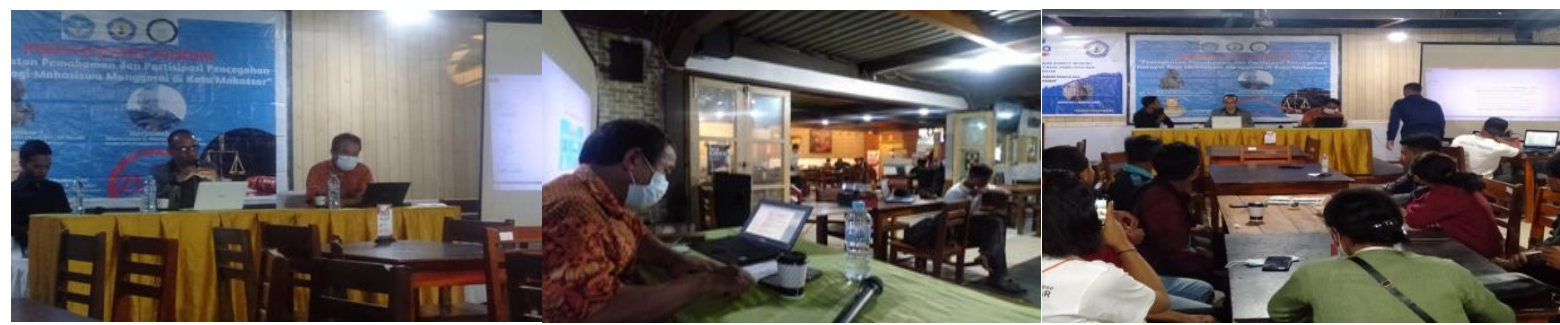

Gambar 1. Foto Kegiatan Penyuluhan

\subsubsection{Analisis Kasus dan Pelatihan Pengawasan serta Mekanisme Pelaporan dugaan Korupsi}

Kegiatan ini bertujuan agar Mahasiswa Manggarai memahami berbagai kasus korupsi di Indonesia serta memahami bagaimana prosedur dan mekanisme pelaporan dugaan korupsi. Banyak mahasiswa Manggarai yang sebenarnya mengetahui adanya dugaan terjadi kejahatan korupsi, tetapi mereka tidak memahami bagaimana cara dan mekanisme pelaporannya. Oleh karena itu kegiatan ini sangat bermanfaat bagi mereka.
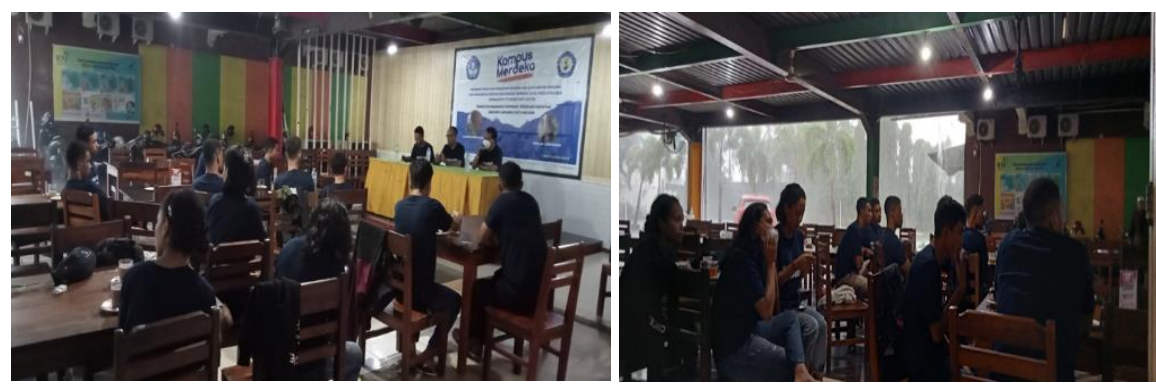

Gambar 2. Kegiatan Analisi Kasus dan Pelatihan Mekanisme Pelaporan

\subsubsection{Deklarasi Anti Korupsi dan Pembentukan Komunitas Anti Korupsi}

Tujuan dari kegiatan PKM ini, tidak hanya memberikan pemahaman tentang korupsi, tetapi juga membangun kesadaran mahasiswa Manggarai tentang pentingnya peran partisipasi dalam mengawal berbagai isu-isu korupsi baik secara nasional maupun local Sulawesi Selatan maupun di daearah asal Manggarai serta mengontrol berbagai kerja-kerja lembaga penegak hukum agar dapat optimal dalam melaksanakan upaya pemberantasan korupsi. Pengawasan tersebut tentunya tidak akan efektif kalau dilakukan sendiri-sendiri, perlu menggalang gerakan bersama dengan membentuk komunitas anti korupsi. Kegiatan PKM yang dilakukan berhasil membentuk Forum Anti Korupsi Mahasiswa Manggarai.
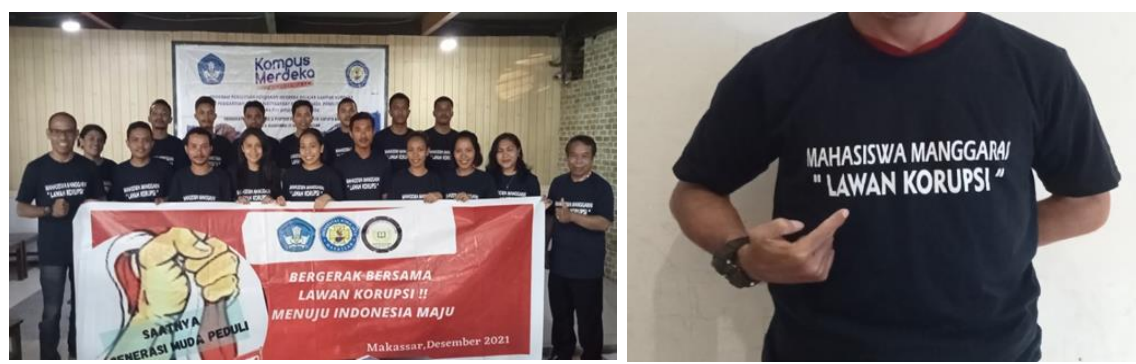

Gambar. 3. Deklarasi Anti Korupsi

\subsection{Manfaat Serta Dampak Yang Diperoleh dari kegiatan PKM yang dilaksanakan}

Ada beberapa manfaat yang diperoleh sebagai hasil dari kegiatan pengabdian kepada masyarakat yang telah dilakukan, yakni:

a. Memberikan gambaran dan pengetahuan yang komprehensif bagi mahasiswa Manggarai tentang korupsi seperti struktur dan bentuk korupsi, Faktor serta upaya-upaya pencegahan korupsi. 
b. Memberikan gambaran tentang beberapa kasus korupsi yang terjadi di Indonesia dan bagaimana upaya upaya penyelesaiannya.

b. Membangun kesadaran mahasiswa Manggarai tentang pentingnya peran partisipasi dalam mengawal berbagai isu-isu korupsi baik secara nasional maupun local Sulawesi Selatan maupun di daearah asal Manggarai serta mengontrol berbagai kerja-kerja lembaga penegak hukum agar dapat optimal dalam melaksanakan upaya pemberantasan korupsi

c. Membangun gerakan bersama dengan membentuk komunitas Anti Korupsi

d. Penguatan dan Internalisasi nilai dan sikap anti Korupsi bagi Mahasiwa ManggaraiMakassar.

e. Mencipakan budaya anti korupsi bagi Masyarakat khususnya Mahasiswa

f. Pencegahan kejahatan korupsi sejak dini

g. Membangun kesadaran masyarakat bahwa memberantas korupsi bukan hanya tanggung jawab aparat penegak hukum tetapi juga merupakan tangung jawab masyarakat termasuk mahasiswa lewat upaya-upaya pengawasan sebagaimana diatur dalam Undang-undang

Selain itu, kontribusi terhadap sektor lain yakni:

a. Membantu kerja aparat penengak hukum dalam mengungkap dan memberantas kejahatan korupsi di Indonesia.

b. Dengan adanya pengawasan oleh masyarakat khususnya mahasiswa, maka aparat penegak hukum dapat bekerja secara optimal dan tehindar dari praktek-praktek korupsi.

c. Dengan adanya pengawasan oleh masyarakat khususnya mahasiswa, pemerintah dapat menjalankan agenda-agenda pememerintahan dan penyeleanggaraan Negara yang bebas korupsi.

\section{KESIMPULAN}

Korupsi merupakan salah satu kejahatan yang dikategorikan sebagai extra ordinary crime atau kejahatan luar biasa, sebab korupsi bukan saja dilakukan secara individu, namun dilakukan secara teroragisir, sistematis dan terstruktur oleh kelompok atau istitusi yang menyebabkan kerugian besar bagi rakyat dan perekonomian bangsa Dalam pencegahan dan pemberantasan korupsi penting dilakukan berbagai cara. Salah satu upaya yang dilakukan adalah dengan pengembangan sistem nilai dan sikap anti korupsi. Hal tersebut dapat dilakukan melalui berbagai kampanye serta memberikan ruang partisipasi bagi masyarakat untuk khususnnya mahasiswa untuk turut berpartisipasi dalam upaya pemberantasan korupsi. Kegiatan pengabdian ini penting untuk terus dikembangkan kedepan. Oleh karena itu perlu dukungan dari semua pihak termasuk pemerintah dalam mefaslitasi berupa sarana dan dana.

\section{UCAPAN TERIMA KASIH}

Penulis Kegiatan Pengabdian Kepada Masyarakat ini dapat dilaksanakan berkat Bantuan Pendanaan Program Penelitian Kebijakan Merdeka Belajar Kampus Merdeka Dan Pengabdian Masyarakat Berbasis Hasil Penelitian Pts Tahun 2021. Untuk itu Ucapan Terima Kasih setinggitingginya kepada Kemendikbud Ristek Dikti Cq Direktorat Jenderal Dikti yang telah memberikan dana bantuan tersebut kepada kami sehingga kami boleh melaksanakan kegiatan pengabdian ini sesuai yang direncanakan. Tidak lupa kami ucapan terima kasih juga kepada Rektor Universitas Atma Jaya Makassar dan Ketua LPPM Univeritas Atma Jaya Makassar yang telah mefasilitasi kami dalam menyelesaikan program pengabdian Masyarakat ini. Semoga kegiatan ini memberikan kontribusi bagi bangsa dan negara khususnya dalam upaya-upaya pemberantasan korupsi di Indonesia. Terima Kasih.

\section{DAFTAR PUSTAKA}

Antaranews.com. (2020), https://www.antaranews.com/berita/1972407/indeks-persepsikorupsi-indonesia-pada-2020-melorot-3- 
poin\#: :text=Jakarta\%20(ANTARA)\%20\%2D\%20Indeks\%20Persepsi,

dari\%20180\%20negara\%20yang\%20disurvei

Hamzah. (1995) Delik-delik Tersebar Di Luar KUHP dengan Komentar, Jakarta, Pradya Paramita.

Kristian, dkk. (2015), Tindak Pidana Korupsi, Kajian Terhadap harmonisasi antara Hukum Nasional dan The United Nations Convention Against Corruption (UNCAC), PT.Refika Aditama, Bandung.

Kpk (2020) https://www.kpk.go.id/id/statistik/penindakan/tpk-berdasarkan-profesi-jabatan

Lopa, dkk. (1987) Undang-undang Tindak Pidana Korupsi(Undang-undang No.3 Tahun 1971)berikut Pembahasan serta Penerapannya Parkatek, Alumni, Bandung.

Mas'oed. (1997).Politik, birokrasi dan Pembangunan, Pustaka Pelajar:Yogyakrta.

Shofie. (2002) Pelaku Usaha, Konsumen dan Tindak Pidana Korporasi, Ghalia Indonesia, Jakarta.

Susanto. (1995) Kejahatan Korporasi, BP UNDIP, Semarang, 1995.

Sudarto. (1997). Hukum dan Hukum Pidana, Bandung, Alumni.

Wasito. (2001) Kamus Bahasa Indonesia, Balai Pustaka, Jokjakarta. 


\section{Halaman Ini Dikosongkan}

